University of Wollongong

Research Online

Faculty of Engineering - Papers (Archive)

Faculty of Engineering and Information

Sciences

$1-1-2011$

\title{
Performance and prediction of vacuum combined surcharge consolidation at Port of Brisbane
}

Buddhima Indraratna

University of Wollongong, indra@uow.edu.au

Cholachat Rujikiatkamjorn

University of Wollongong, cholacha@uow.edu.au

Xueyu Geng

University of Wollongong, xgeng@uow.edu.au

Jayantha Ameratunga

Peter Boyle

Follow this and additional works at: https://ro.uow.edu.au/engpapers

Part of the Engineering Commons

https://ro.uow.edu.au/engpapers/1062

\section{Recommended Citation}

Indraratna, Buddhima; Rujikiatkamjorn, Cholachat; Geng, Xueyu; Ameratunga, Jayantha; and Boyle, Peter: Performance and prediction of vacuum combined surcharge consolidation at Port of Brisbane 2011, 45-60.

https://ro.uow.edu.au/engpapers/1062

Research Online is the open access institutional repository for the University of Wollongong. For further information contact the UOW Library: research-pubs@uow.edu.au 


\title{
PERFORMANCE AND PREDICTION OF VACUUM COMBINED SURCHARGE CONSOLIDATION AT PORT OF BRISBANE
}

\author{
Buddhima Indraratna ${ }^{1}$, Cholachat Rujikiatkamjorn ${ }^{2}$, Geng Xueyu ${ }^{3}$, Jayantha Ameratunga ${ }^{4}$ and Peter \\ Boyle $^{5}$ \\ ${ }^{1}$ Professor, ${ }^{2}$ Senior Lecturer, ${ }^{3}$ Research Fellow; School of Civil, Mining and Environmental Engineering, \\ University of Wollongong, ${ }^{4}$ Senior Principal, Coffey Geotechnics, Qld, \\ ${ }^{5}$ Formerly of Port of Brisbane (Corporation) Pty Ltd, QLD
}

\begin{abstract}
During the past decade, the application of vacuum preloading for stabilising soft coastal clay and other low-lying estuarine soils has become popular in Australia. The cost-effectiveness is a major factor in most projects in view of the significantly reduced time for achieving a relatively high degree of consolidation. Due to an increase in trade activities at the Port of Brisbane, new facilities on Fisherman Islands at the mouth of the Brisbane River will be constructed on the new outer area (235 ha) adjacent to the existing port facilities via land reclamation. A vacuum assisted surcharge load and conventional surcharge scheme in conjunction with prefabricated vertical drains was selected to reduce the required consolidation time through the deeper subsoil layers. The design of the combined vacuum and surcharge fill system and the construction of the embankment are described in this paper. A comparison of the performance of the vacuum combined surcharge loading system with a standard surcharge fill highlights the clear benefits of vacuum consolidation. Field monitoring data are presented to demonstrate how the embankment performed during construction. The paper also evaluates the relative performance of the two contrasting vacuum preloading systems (i.e. membrane and membraneless systems. An analytical solution for radial consolidation considering both time-dependent surcharge loading and vacuum pressure is proposed to predict the settlements and associated excess pore pressures of the soft Holocene clay deposits.
\end{abstract}

\section{INTRODUCTION}

Coastal regions of Australia contain soft clays, which have unacceptable geotechnical properties such as low shear strength and high compressibility. In the absence of suitable ground improvement, excessive differential settlement and lateral movement unfavourably affect the stability of buildings and port infrastructure built on such soft ground (Holtz et al.,1991, Indraratna and Redana, 2000). A system of vertical drains with a combined vacuum and surcharge preloading is an effective method for promoting radial flow, which accelerates soil consolidation. The behaviour of soft clay stabilized with vertical drains and vacuum pressure can now be predicted with acceptable accuracy due to significant progress that has been made in the past decade through rigorous analytical and numerical analysis. Mohamedelhassan and Shang (2002) proposed an analytical solution for one-dimensional consolidation with vacuum application. Indraratna et al. (2005) extended the unit cell radial consolidation theory for vacuum application with instantaneous loading considering the vacuum loss along the drain length.

The Port of Brisbane is Australia's third largest container port located between the mouth of the Brisbane River and Fisherman Islands (Indraratna et al., 2011). With rapid growth in trading activities, a new outer area (235 ha) adjacent to the current port facilities is being reclaimed to maximise the available land, and to provide the additional berths suitable for cargo and container handling. In this area, the soil profile comprises a highly compressible clay layer over $30 \mathrm{~m}$ in thickness with an undrained shear strength of less than $15 \mathrm{kPa}$ near the surface. The strength of the dredged mud used for reclamation has a much lower shear strength depending on the time of placement and the duration the capping material (surcharge) had been in place. Without surcharge preloading, it is determined that the consolidation will take more than 50 years with vertical settlements of 2.5$4.0 \mathrm{~m}$ expected under the required service loadings. Therefore, vacuum consolidation with prefabricated vertical drains (PVDs) was suggested to speed up the consolidation process and to limit horizontal deformation for the site located immediately adjacent to the Moreton Bay Marine Park (Austress Menard 2008).

Chu et al. (2000) and Chai et al. (2005) discussed the application of the vacuum preloading combined with PVDs. In this method, the suction can propagate to a greater depth of the subsoil using the PVD system. Also, lengthy consolidation time due to stage construction can be minimized (Indraratna et al., 2005). The surcharge fill height may be lowered by several metres, if a vacuum pressure of at least $70 \%$ the atmospheric pressure is sustained (Rujikiatkamjorn et al., 2008). In addition, the embankment construction rate can be increased with the reduction in the number of construction stages (Yan and Chu, 2003). Once the soil increases its stiffness and shear strength due to consolidation, the post-construction settlement can be considerably less, thereby reducing risk of differential settlement (Shang et al., 1998). The ground improvement provided by PVDs combined with 
vacuum pressure may be an economically attractive alternative in deep soft clay sites. To date, there is no comprehensively reported case history where both the conventional surcharge preloading and vacuum technique are applied in the same area with different drain types and spacing.

In this paper, the performance comparison between the vacuum and non-vacuum area has been made based on the measured vertical deformations, excess pore pressures and horizontal displacements. The effects of drain spacing, drain type and improvement technique are elaborated based on the observed degree of consolidation. The analytical solutions for radial consolidation considering both time dependent surcharge loading and vacuum pressure are proposed to predict settlement and associated excess pore pressure.

\section{ANALYTICAL SOLUTIONS FOR VACUUM PRELOADING SYSTEMS}

\subsection{VACUUM PRELOADING SYSTEMS}

Currently, there are two main types of vacuum preloading systems aopted in the field (Geng et al., 2011):

A. Membrane system: After PVDs are installed and the sand blanket is placed with horizontal perforated pipes, the membrane is laid on the top and its borders are submerged under a bentonite slurry trench (Figure 1a). The vacuum pumps are then attached to the discharge system. A major advantage of this system is that the vacuum can distribute within the sand platform, along the soil surface and down the PVDs. However, an obvious drawback is that the efficiency of the entire system depends on the ability of the airtight system to prevent any air leaks over a significant period of time.

B. Membraneless system: When an area has to be subdivided and progressed individually, the vacuum preloading can only be conducted one section after another and therefore the membrane system may not be an economical solution. To avoid this problem, the vacuum pipes are connected directly to each individual PVD using a tubing system (Figure 1b). In contrast to the membrane system where any air leak can affect the entire system, each drain acts independently. However, the requirement of significant tubing for hundreds of drains can affect the installation time and cost.

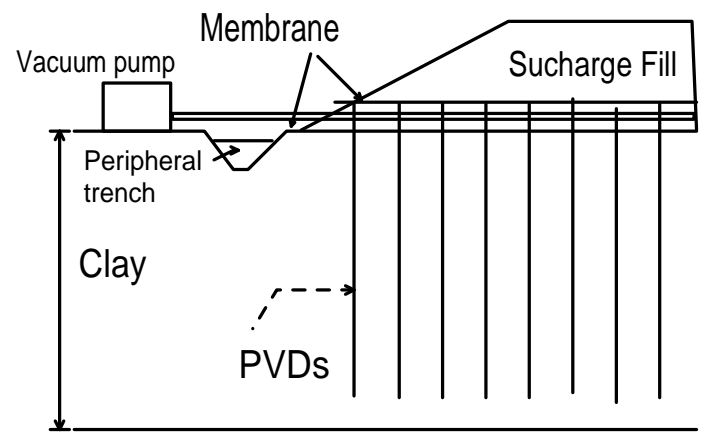

(a)

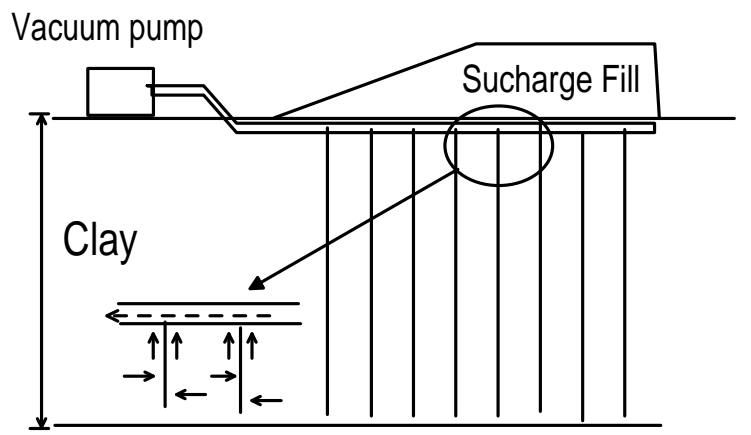

(b)

Figure 1: Types of vacuum preloading systems (a) Membrane system and (b) Membraneless system.

\subsection{GOVERNING EQUATIONS}

\section{A. Membrane system}

In a membrane system, the vacuum propagates from the horizontal drain through layer of sand, PVDs, and layer of clay (Figure 2a). This three dimensional flow in the sand blanket beneath the membrane ( $0 \leq z \leq L_{w}$ ) can be expressed as:

$$
\begin{gathered}
\frac{\partial \varepsilon_{v 1}}{\partial t}=-m_{v 1}\left(\frac{\partial \bar{u}_{1}}{\partial t}-\frac{d q}{d t}\right) \\
-\frac{k_{h 1}}{\gamma_{w}}\left(\frac{1}{r} \frac{\partial u_{1}}{\partial r}+\frac{\partial^{2} u_{1}}{\partial r^{2}}\right)-\frac{k_{v 1}}{\gamma_{w}} \frac{\partial^{2} \bar{u}_{1}}{\partial z^{2}}=\frac{\partial \varepsilon_{v 1}}{\partial t} \quad r_{w} \leq r \leq r_{e} \\
\frac{\partial^{2} u_{w 1}}{\partial z^{2}}=-\left.\frac{2 k_{h 1}}{r_{w} k_{v 1}} \frac{\partial u_{1}}{\partial r}\right|_{r=r_{w}}
\end{gathered}
$$




$$
\bar{u}_{1}=\frac{1}{\pi\left(r_{e}^{2}-r_{w}^{2}\right)} \int_{r_{w}}^{r_{e}} 2 \pi r u_{1} d r
$$

The governing equations for the underlying soil ( $L_{w} \leq z \leq H$ ), may be expressed as:

$$
\begin{gathered}
\frac{\partial \varepsilon_{v 2}}{\partial t}=-m_{v 2}\left(\frac{\partial \bar{u}_{2}}{\partial t}-\frac{d q}{d t}\right) \\
-\frac{k_{s 2}}{\gamma_{w}}\left(\frac{1}{r} \frac{\partial u_{s 2}}{\partial r}+\frac{\partial^{2} u_{s 2}}{\partial r^{2}}\right)-\frac{k_{v 2}}{\gamma_{w}} \frac{\partial^{2} \bar{u}_{2}}{\partial z^{2}}=\frac{\partial \varepsilon_{v 2}}{\partial t} \quad r_{w} \leq r \leq r_{s} \\
-\frac{k_{h 2}}{\gamma_{w}}\left(\frac{1}{r} \frac{\partial u_{n 2}}{\partial r}+\frac{\partial^{2} u_{n 2}}{\partial r^{2}}\right)-\frac{k_{v 2}}{\gamma_{w}} \frac{\partial^{2} \bar{u}_{2}}{\partial z^{2}}=\frac{\partial \varepsilon_{v 2}}{\partial t} \quad r_{s} \leq r \leq r_{e} \\
\frac{\partial^{2} u_{w 2}}{\partial z^{2}}=-\left.\frac{2 k_{s 2}}{r_{w} k_{w}} \frac{\partial u_{s 2}}{\partial r}\right|_{r=r_{w}} \\
\bar{u}_{2}=\frac{1}{\pi\left(r_{e}^{2}-r_{w}^{2}\right)}\left(\int_{r_{w}}^{r_{s}} 2 \pi r u_{s 2} d r+\int_{r_{s}}^{r_{e}} 2 \pi r u_{n 2} d r\right)
\end{gathered}
$$

The boundary conditions for both the radial and vertical directions are as follows:

$$
\begin{aligned}
& r=r_{e}: \frac{\partial u_{n 2}}{\partial r}=0, \frac{\partial u_{1}}{\partial r}=0 \\
& r=r_{s}: k_{s 2} \frac{\partial u_{s 2}}{\partial r}=k_{h 2} \frac{\partial u_{n 2}}{\partial r} \\
& r=r_{s}: u_{s 2}=u_{n 2} \\
& r=r_{w}: u_{s 2}=u_{w 2}, \bar{u}_{1}=u_{w 1} \\
& z=0: u_{w 1}=p, \bar{u}_{1}=p \\
& z=H: \frac{\partial u_{w 2}}{\partial z}=0, \frac{\partial \bar{u}_{2}}{\partial z}=0
\end{aligned}
$$

Continuity at the interface between the sand blanket and underlying layer of soil ( $z=L_{w}$ ) may be then written as:

The initial condition is:

$$
\begin{aligned}
& \mathrm{Z}=L_{w}: u_{w 1}=u_{w 2} \\
& \mathrm{Z}=L_{w}: \bar{u}_{1}=\bar{u}_{2} \\
& \mathrm{Z}=L_{w}: k_{v 1} \frac{\partial u_{w 1}}{\partial z}=k_{w} \frac{\partial u_{w 2}}{\partial z} \\
& Z=L_{w}: k_{v 1} \frac{\partial \bar{u}_{1}}{\partial z}=k_{v 2} \frac{\partial \bar{u}_{2}}{\partial z}
\end{aligned}
$$

$$
\text { At } t=0, \bar{u}_{1}=\bar{u}_{2}=u_{0}(z)=q_{0}
$$

where $i$ is the index number of arbitrary layer, $(i=1,2), r_{s i}$ is the radius of smear zone, $r_{e}$ is the radius of influence zone, $r$ is the radial coordinate, $z$ is the vertical coordinate, $t$ is the time, $\varepsilon_{v i}$ is the vertical strain, $m_{v i}$ is the coefficient of volume compressibility of soil, $k_{h i}$ is the horizontal coefficient of permeability of soil, $k_{v i}$ is the vertical coefficient of permeability of the soil, $k_{w}$ is the coefficient of permeability of the vertical drain, $\bar{u}_{i}$ is the average pore pressure, $u_{s i}$ is the pore pressure at any point in the smear zone, $u_{n i}$ is the pore pressure at any point in the natural soil zone, $u_{w i}$ is the excess pore water pressure within the vertical drain, $q$ is the time-dependent surcharge preloading, $q_{0}$ is the initial value of preloading, $L_{w}$ is the thickness of the sand layer, $H$ is the thickness of the whole layer (i.e., for the membrane system, (both sand blanket and clay layer, and for the membraneless system, only the clay layer), $p$ is the vacuum pressure. 


\section{B. Membraneless system}

The main difference between a membrane system and a membraneless system is in the boundary conditions. In the membraneless system a vacuum pump is connected directly to individual PVD's through a system of horizontal pipes (Figure 2b). The governing equations and initial conditions of underlying soil improved by PVD's are the same as for the membrane system (Equation 10a-Equation 10d and Equation 10k). In order to study the loss of vacuum, the vacuum pressure along the boundary of the drain was considered to vary linearly from $p$ at the top of the drain to $\eta p$ at the bottom, where $\eta$ is a ratio between the vacuum at the top and bottom of the drain. The value of $\eta$ varies between 0 and 1 . If there is no vacuum loss at the bottom of the PVDs $\eta=1$, and if vacuum pressure is 0 at the bottom of the drain, $\eta=0$.

The boundary conditions for a membraneless system are:

$$
\begin{aligned}
& z=0: u_{w}=p, \frac{\partial \bar{u}}{\partial z}=0 \\
& z=H: \frac{\partial u_{w}}{\partial z}=\frac{\eta-1}{H} p, \frac{\partial \bar{u}}{\partial z}=0
\end{aligned}
$$

The analytical solutions based on the above governing equations and boundary conditions are given in Appendix 1 for both membrane and membraneless systems.

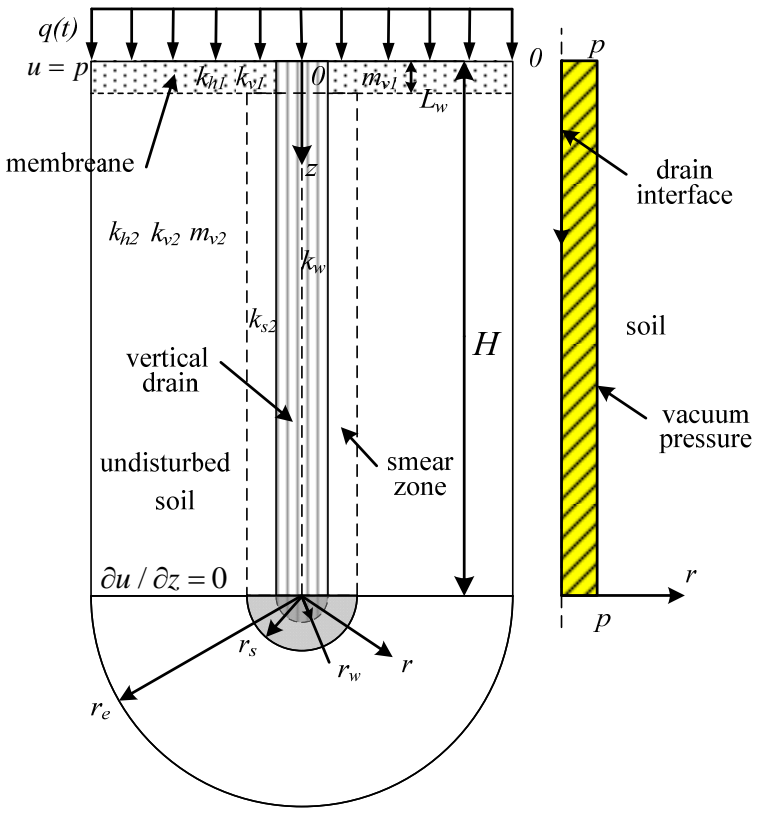

(a)

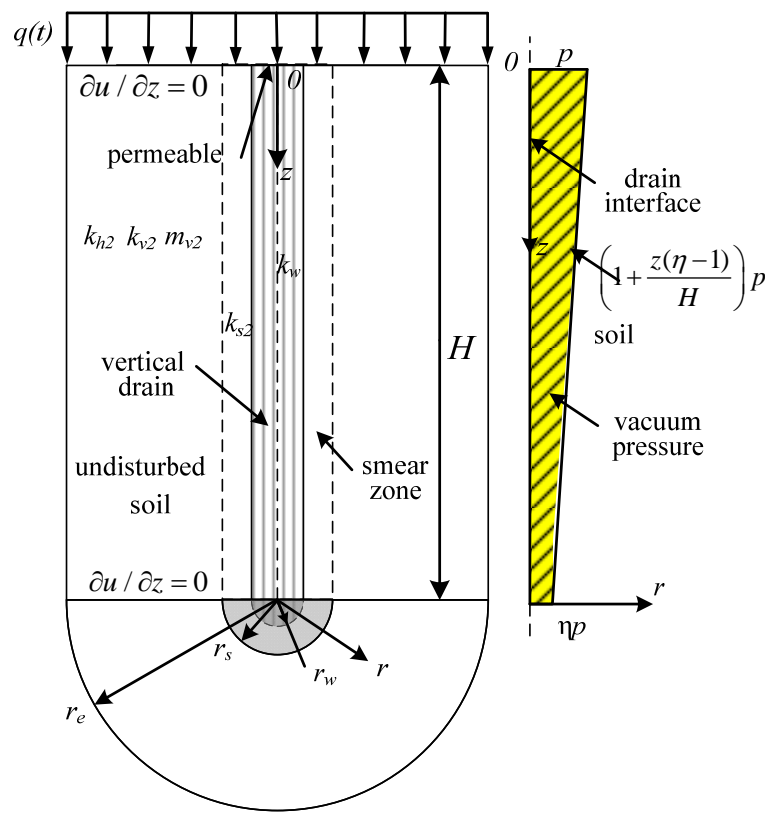

(b)

Figure 2: Analysis schemes of unit cell with vertical drain: (a) membrane system and (b) membraneless system (Geng et al., 2011)

\section{GENERAL DESCRIPTION OF EMBANKMENT CHARACTERISTICS AND} SITE CONDITIONS

In 2003, the Port of Brisbane Corporation started to reclaim a sub-tidal land area of 235 ha at Fisherman Islands near the mouth of the Brisbane River (Figure 3). The reclaimed land is expected to provide additional berths and associated infrastructure to accommodate the future growth of the Port (Port of Brisbane Corporation 2009). To compare the performance of the vacuum system with the non-vacuum system (PVD and surcharge load), a trial area (S3A) shown in Figure 4 was subdivided into WD1-WD5 (Non-vacuum areas) and VC1-VC2 (Vacuum areas). The subdivision areas ranged from $1500 \mathrm{~m}^{2}$ to $11000 \mathrm{~m}^{2}$. After drying, the mud was capped off with a few metres of dredged sand, which performs as a working platform for PVD installation rigs, while providing a drainage layer for vacuum system.

The upper Holocene sand underneath the dredged mud was about 2-3 m thick, and overlaid the Holocene clay layer having a thickness from $6 \mathrm{~m}$ to $25 \mathrm{~m}$. The highly compressible Holocene clay layer had a low shear strength and is generally referred to as PoB clay (Ameratunga et al., 2010). The Holocene layer overlies a Pleistocene deposit comprising of highly over-consolidated clay. Site investigations including cone 
penetration/piezocone tests, dissipation tests, boreholes, field vane shear tests and oedometer tests were carried out to assess the consolidation and stability design parameters. The soil profile and the corresponding soil properties are shown in Figure 5, where groundwater level is at $+3.5 \mathrm{~m} \mathrm{RL}$. The water contents of the soil layers were at or beyond their liquid limits. The field vane tests indicate that the undrained shear strength of the dredged mud and the Holocene clays varied from $5 \mathrm{kPa}$ to $60 \mathrm{kPa}$. The compression index $\left(\mathrm{C}_{\mathrm{c}}\right)$ varied from 0.1 1.0. The coefficient of consolidation in vertical direction $\left(c_{v}\right)$ was approximately the same as that in horizontal direction $\left(c_{h}\right)$ for the totally remoulded dredged mud layer, while $c_{v} / c_{h}$ is about 2 for the Holocene clay layer.

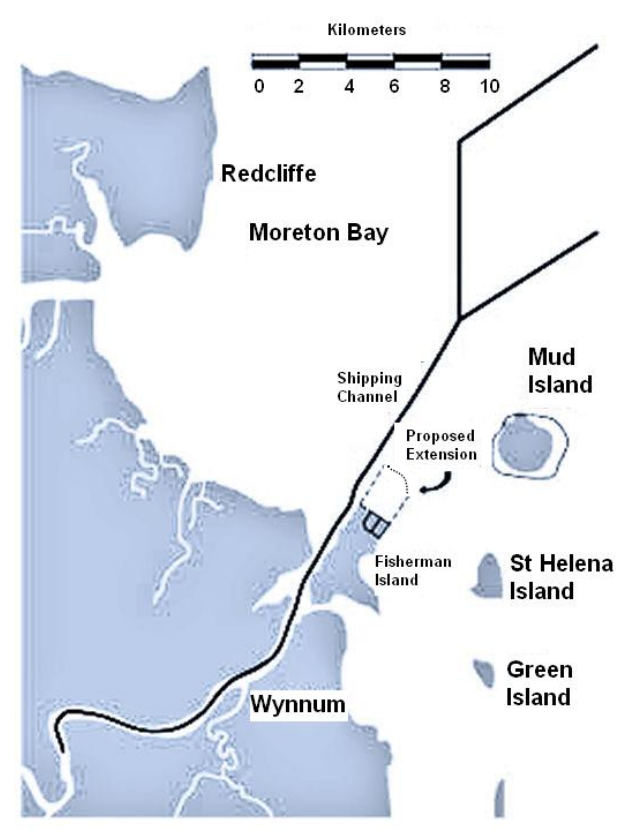

Figure 3. Map of the proposed extension area at the Port of Brisbane (adopted from Port of Brisbane Corporation, 2009)

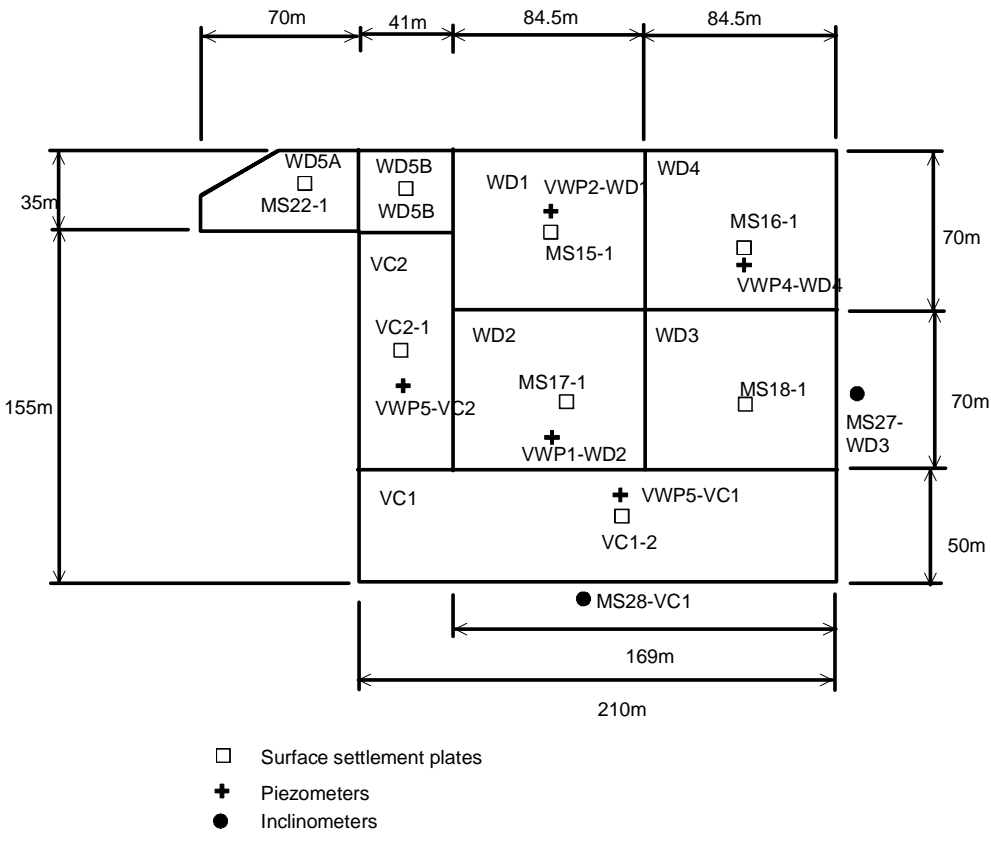

Figure 4. Site layout for S3A with instrumentation plan (Indraratna et al., 2011)

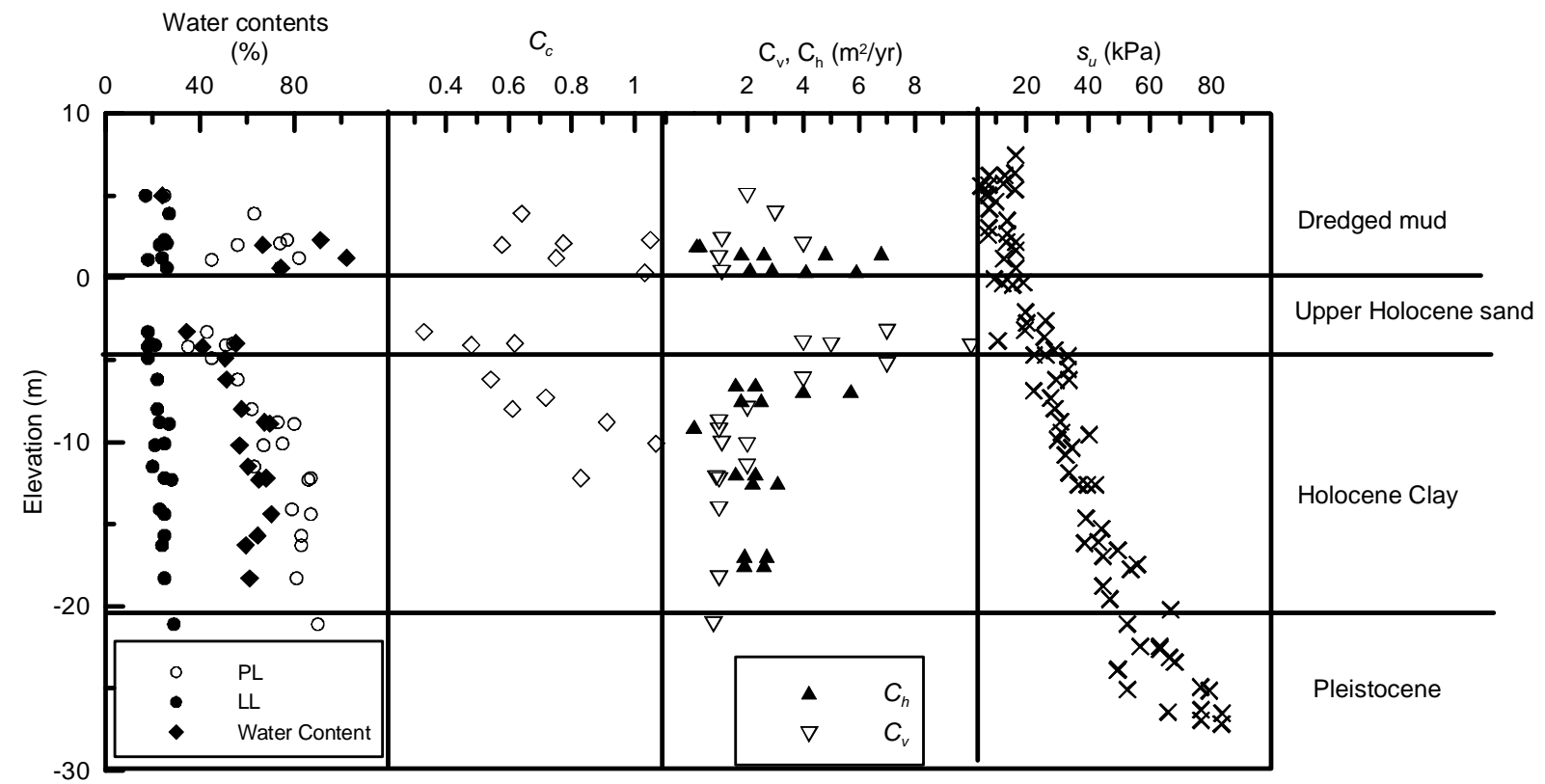

Figure 5: Soil properties and profile at S3A, Port of Brisbane (Indraratna et al., 2011)

As the Holocene clay layer is quite thick, two preloading approaches were used to minimise the long term settlement including conventional surcharge preloading system and the membrane-type vacuum consolidation system both applied to PVDs. The surcharge preloading system was employed in the inner areas (WD1-WD5) whilst, in the outer area (VC1 and VC2) close to the Marine Park, the vacuum combined preloading approach was applied to control the excessive lateral displacement to minimise disturbance of the marine habitats. Rigorous design specifications were considered for the design and construction of fill embankments and vacuum 
application over the soft Holocene deposits: (a) Service load of 15-25 kPa, (b) maximum residual settlement of not more than $250 \mathrm{~mm}$ over 20 years after the application of service load. The surcharge embankment heights varied from $3.0 \mathrm{~m}$ to $9.0 \mathrm{~m}$. Based on the design criteria, Table 1 presents the PVD characteristics and treatment types applied to each section. In non-vacuum areas, both circular and band shape PVDs were installed in a square pattern at a spacing varying between 1.1-1.3 $\mathrm{m}$. The lengths of drains were from $6 \mathrm{~m}$ to $28.7 \mathrm{~m}$ across the site as shown in the Table 1 . The variation in drain lengths was owing to the non-uniform clay thickness. At this site, wick drains (Band Drain Type-A and Band Drain Type-B) typically had dimensions of $100 \mathrm{~mm} \times 4 \mathrm{~mm}$, and the circular drains had an internal diameter of $34 \mathrm{~mm}$. The Authors have purposely omitted the commercial brand names of all PVDs used.

To observe the ground behaviour, several instruments were installed including settlement plates, vibrating wire piezometers, magnetic extensometers and inclinometers. Their locations were shown earlier in Figure 4 . The inclinometers were essential because failure adjacent to the Moreton Bay Marine Park was not acceptable. The vibrating wire inclinometers were installed under the test embankment at various depths (Table 2).

In the vacuum area, circular PVDs were installed at a single spacing of $1.2 \mathrm{~m}$ in a square pattern in conjunction with the airtight membrane, horizontal perforated pipes connected to the heavy duty pumps that represented the vacuum system. The membrane boundary was embedded in a flooded soil-bentonite peripheral trench (Figure 6) to ensure absolute air tightness during its operation (Berthier et al., 2009). The actual suction varied from -60 $\mathrm{kPa}$ to $-75 \mathrm{kPa}$, and no air leaks were encountered during vacuum application that ensured the intact seal provided by the membrane. A vacuum pressure of $70 \mathrm{kPa}$ was applied in VC1 and VC2 areas after 40 days. The 'leak test' was conducted at all welding joints to ensure a perfect seal. Four vacuum pump modules were connected to the discharge system extending from the trenches. An obvious benefit of the membrane-based system is that the suction propagates along the soil surface and down the PVDs within the airtight domain provided by the cut-off wall.

Table 1. PVD characteristics and improvement scheme (Indraratna et al., 2011)

\begin{tabular}{|c|l|c|c|c|c|l|}
\hline Section & Drain type & $\begin{array}{c}\text { Drain length } \\
(\mathrm{m})\end{array}$ & $\begin{array}{c}\text { Drain spacing in } \\
\text { square pattern } \\
(\mathrm{m})\end{array}$ & $\begin{array}{c}\text { Clay thickness } \\
(\mathrm{m})\end{array}$ & $\begin{array}{c}\text { Total fill } \\
\text { height } \\
(\mathrm{m})\end{array}$ & $\begin{array}{l}\text { Treatment } \\
\text { scheme }\end{array}$ \\
\hline WD1 & $\begin{array}{l}\text { Circular drains }-34 \mathrm{~mm} \\
\text { diameter }\end{array}$ & $14.5-18.5$ & 1.1 & $12.0-15.5$ & 5.2 & Surcharge \\
\hline WD2 & $\begin{array}{l}\text { Circular drains }-34 \mathrm{~mm} \\
\text { diameter }\end{array}$ & $22.5-27.5$ & 1.3 & $20.0-23.5$ & $7-7.2$ & Surcharge \\
\hline WD3 & $\begin{array}{l}\text { Band drain Type-A } \\
\left(100 \times 4 \mathrm{~mm}^{2}\right)\end{array}$ & $17.1-23.5$ & 1.1 & $14.0-17.0$ & $4.3-4.6$ & Surcharge \\
\hline WD4 & $\begin{array}{l}\text { Band drains Type-A } \\
\left(100 \times 4 \mathrm{~mm}^{2}\right)\end{array}$ & $27.0-28.7$ & 1.3 & $22.5-24.5$ & 6.1 & Surcharge \\
\hline WD5A & $\begin{array}{l}\text { Band drains Type-B } \\
\left(100 \times 4 \text { mm }{ }^{2}\right)\end{array}$ & $6.0-8.0$ & 1.2 & $6.0-8.0$ & 3.3 & Surcharge \\
\hline WD5B & $\begin{array}{l}\text { Band drains Type-B } \\
\left(100 \times 4 \text { mm }{ }^{2}\right)\end{array}$ & 13.5 & 1.1 & 9.5 & 5.5 & Surcharge \\
\hline VC1 & $\begin{array}{l}\text { Circular drains }-34 \mathrm{~mm} \\
\text { diameter }\end{array}$ & $14.0-26.5$ & 1.2 & $9.0-21.0$ & 3.2 & $\begin{array}{l}\text { Surcharge+ } \\
70 \mathrm{kPa} \text { vacuum }\end{array}$ \\
\hline VC2 & $\begin{array}{l}\text { Circular drains }-34 \mathrm{~mm} \\
\text { diameter }\end{array}$ & $15.5-22.5$ & 1.2 & $12.5-18.5$ & 2.8 & $\begin{array}{l}\text { Surcharge+ } \\
70 \mathrm{kPa} \text { vacuum }\end{array}$ \\
\hline
\end{tabular}

Figure 7 shows the measured pore pressure obtained from the piezometer installed within a circular PVD at $10 \mathrm{~m}$ depth in the vacuum consolidation (VC) area. After membrane installation and vacuum pump operation, the measured suction applied for a year was approximately $65 \mathrm{kPa}$ which was established within a few days. This indicated that the vacuum pressure consistently distributed along the depth. The soil profiles for each area are tabulated in Table 3. The variation of the Holocene clay depth is significant from one to another, with the depth of Lower Holocene clay changing from about $6 \mathrm{~m}$ (VC1) to $23 \mathrm{~m}$ (WD4). The thickness of the Upper Holocene Clay was from about $1.5 \mathrm{~m}$ (WD4) to about $5 \mathrm{~m}$ (WD2). Accurate assessment of the dredged mud layer thickness may not be possible because of lateral spreading, but it is estimated to vary from a relative small thickness of $0.75 \mathrm{~m}$ at VC2 area to about $4.0 \mathrm{~m}$ in WD5B area. 
Table 2: Installation depth of inclinometers (Indraratna et al., 2011)

\begin{tabular}{|c|c|}
\hline Inclinometer No. -Area & Installation Depth from sand platform (m) \\
\hline VWP2-WD1 & 5 \\
\hline VWP1-WD2 & 5 \\
\hline VWP5-WD4 & 18 \\
\hline VWP5-VC1 & 10 \\
\hline VWP5-VC2 & 10 \\
\hline
\end{tabular}

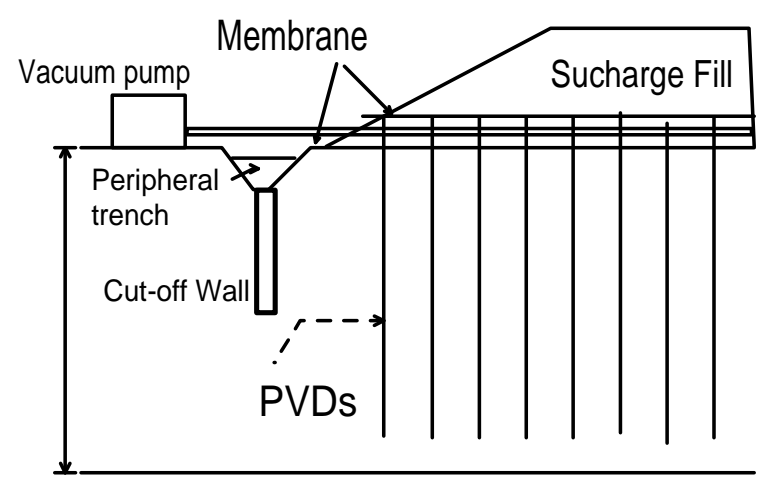

Figure 6: Vacuum consolidation with membrane system and cut-off wall (Indraratna et al., 2011)

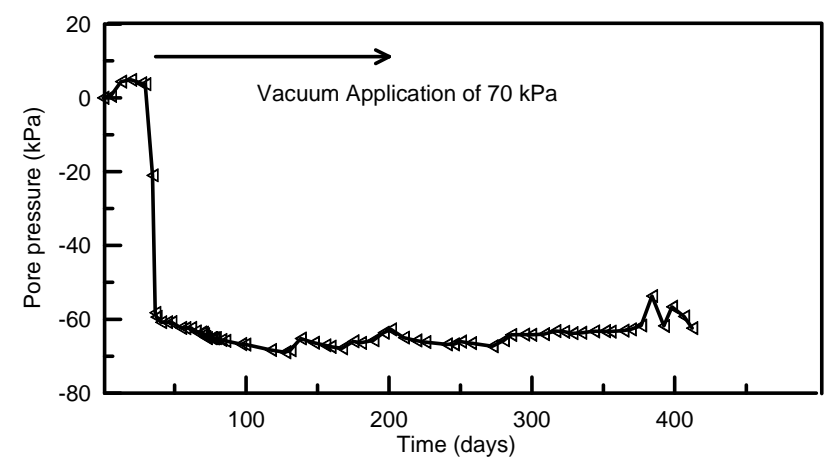

Figure 7: In-drain pore pressure measurements at $10 \mathrm{~m}$ depth in vacuum areas (Indraratna et al., 2011)

Table 3: Soil profiles for individual sections (Indraratna et al., 2011).

\begin{tabular}{|l|c|c|c|c|}
\hline \multirow{2}{*}{ Area } & \multicolumn{4}{|l|}{ Layer Thickness (m) } \\
\cline { 2 - 5 } & Dredged Mud & Upper Holocene Sand & Upper Holocene Clay & Lower Holocene Clay \\
\hline WD1 & $2-3$ & $1-2$ & $4-6$ & $10-12$ \\
\hline WD2 & $1-2.5$ & $1-3$ & $2-5$ & $18-20$ \\
\hline WD3 & $2-4$ & $1-3$ & $2-3$ & $8-15$ \\
\hline WD4 & $1.5-2.2$ & $1-2$ & $1.5-3.5$ & $18-23$ \\
\hline WD5A & $0-1$ & $0-1$ & $2-4$ & $6-8$ \\
\hline WD5B & $2-4$ & $1-2$ & $2-4$ & $7-8$ \\
\hline VC1 & $2-3$ & $2-3$ & $2-3$ & $5-18$ \\
\hline VC2 & $0.5-2.5$ & $2-3$ & $2-3$ & $9-16$ \\
\hline
\end{tabular}

\section{ANALYSIS OF FIELD DATA}

The embankment and foundation behaviours were monitored using an array of settlement plates, piezometers and inclinometers. The embankment heights were from $3 \mathrm{~m}$ to $9 \mathrm{~m}$ depending on the thickness of the clay layer. The embankment responses including vertical displacements and excess pore pressures together with the staged construction of the embankments are presented in Figure 8. It can be seen that the settlement curves are very similar where the settlement takes place more swiftly at the initial consolidation stage. The magnitude of ultimate settlement relies on the clay thickness and embankment height. The maximum settlement is in the WD4 area having the greatest clay thickness (19-26 m), while the minimum settlement occurs in WD5A area in which the clay layer is relatively thin $(8-12 \mathrm{~m})$.

Table 4 presents a summary of the settlement-based degree of consolidation (DOC) for selected settlement plate locations and three drain types used in S3A area, namely Circular Drain, Band Drain Type-A and Band Drain Type-B. There is no distinct relationship between the drain types and the target DOC according to the settlement - based analysis. It is important to note that the DOC achieved in VC2 is higher than the surcharge only areas. Based on Table 4, some relevant observations are summarized below, while recognizing the limitations in comparing different sections that have different soil profiles and surcharge fill heights.

(i) For relatively close drain spacing of $1.1 \mathrm{~m}$, all three types of drains performed equally well based on the DOC values. This is a reasonable comparison, because, both WD1 and WD3 have similar clay thickness @ 14-15 m, and similar fill heights @ 4.5-5.2 m, thereby giving a clay thickness to fill height ratio of about 3. 
(ii) For increased drain spacing of $1.3 \mathrm{~m}$, Band Drain-A and Circular Drains again performed equally well. This is also a good comparison, because, the mean clay thickness is 22-23 m in WD2 and WD4 areas also subjected to similar fill heights @ 6-7 m, thereby giving a clay thickness to fill height ratio of about 3 also.

(iii) By increasing the spacing of Band Drain Type-A from $1.1 \mathrm{~m}$ (WD3) to $1.3 \mathrm{~m}$ (WD4), there is no apparent loss in the DOC attained after 400 days. One would expect that at closer spacing, the smear effects would become increasingly more significant, and the expected increase in consolidation at closer spacing could be compromised. Therefore, this comparison implies that a spacing of $1.3 \mathrm{~m}$ would be sufficient to achieve a relatively high DOC at a given time period.

(iv) Band Drain Type-B installed at spacing of $1.1 \mathrm{~m}$ (WD5B) and $1.2 \mathrm{~m}$ (WD5A) also contribute to similar DOC as that of Type-B. However, this comparison has limitations because of the smaller number of Type B drains used in the trial areas. Nevertheless, given that Type B was one of the most economical wick drain brands in the market, it was pleasing to see their performance in par with the more costly Type A drains.

Table 4: Degree of consolidation of various sections (Indraratna et al., 2011)

\begin{tabular}{|c|c|c|}
\hline Sections & Drain type & $\begin{array}{l}\text { Calculated degree of consolidation after } \\
\text { 400 days (Strain-based) }\end{array}$ \\
\hline WD1 & Circular drains - 34mm diameter & 92 \\
\hline WD2 & Circular drains - 34mm diameter & 82 \\
\hline WD3 & Band drain-A $\left(100 \times 4 \mathrm{~mm}^{2}\right)$ & 87 \\
\hline WD4 & Band drains-A $\left(100 \times 4 \mathrm{~mm}^{2}\right)$ & 85 \\
\hline WD5A & Band drains-B $\left(100 \times 4 \mathrm{~mm}^{2}\right)$ & 94 \\
\hline WD5B & Band drains-B $\left(100 \times 4 \mathrm{~mm}^{2}\right)$ & 92 \\
\hline VC1 & Circular drains - 34mm diameter & 87 \\
\hline VC2 & Circular drains - 34mm diameter & 90 \\
\hline
\end{tabular}

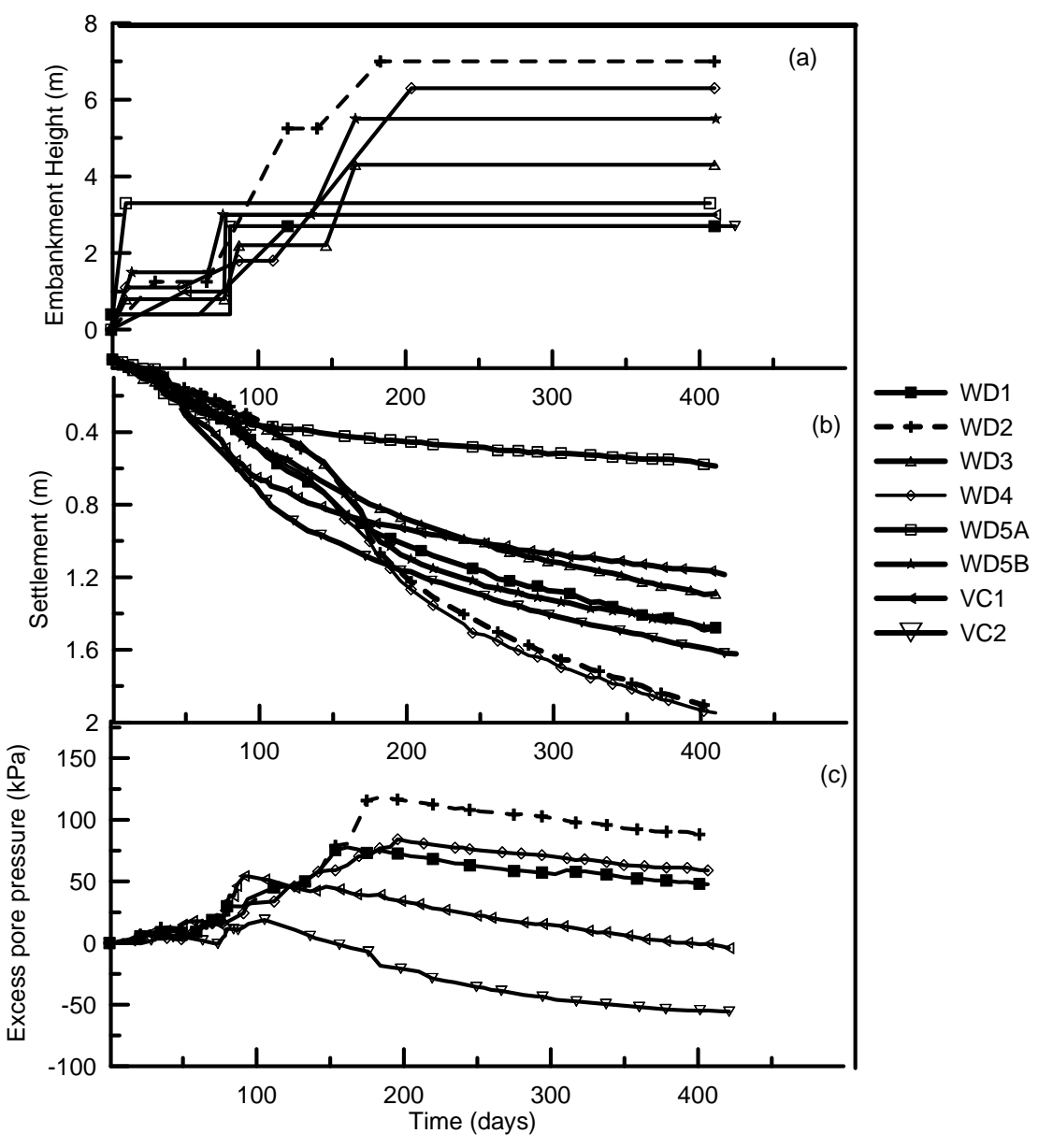

Figure 8: Embankment responses (a) staged construction, (b) settlements and (c) excess pore pressures (Indraratna et al., 2011) 
The measured pore pressures are plotted in Figure 8c, showing a comprehensive picture of the effect of surcharge loading on the development of excess pore water pressure. Although the pore pressure data are limited compared to the large array of settlement data, these results clearly show the extent of excess pore pressure increases due to total stress increase, and the time dependent excess pore pressure dissipation. In order to compare system performance in terms of pore pressure dissipation, the excess pore water pressure reduction with time is plotted in Figure 9. VC1 and VC2 provide the best treatment in view of excess pore pressure dissipation rates, compared to the surcharge only areas. It implies that the circular drain performs better in vacuum areas because the circular drains assist the vacuum pressure propagation more effectively (without losing suction head) than the band drains, thereby allowing a constant vacuum pressure at a greater depth. While the fill height reduces in vacuum areas, thereby involving less filling operations, the applied suction $(-70 \mathrm{kPa})$ compensates for the accelerated excess pore pressure dissipation rates, confirming the effective performance of the vacuum consolidation technique.

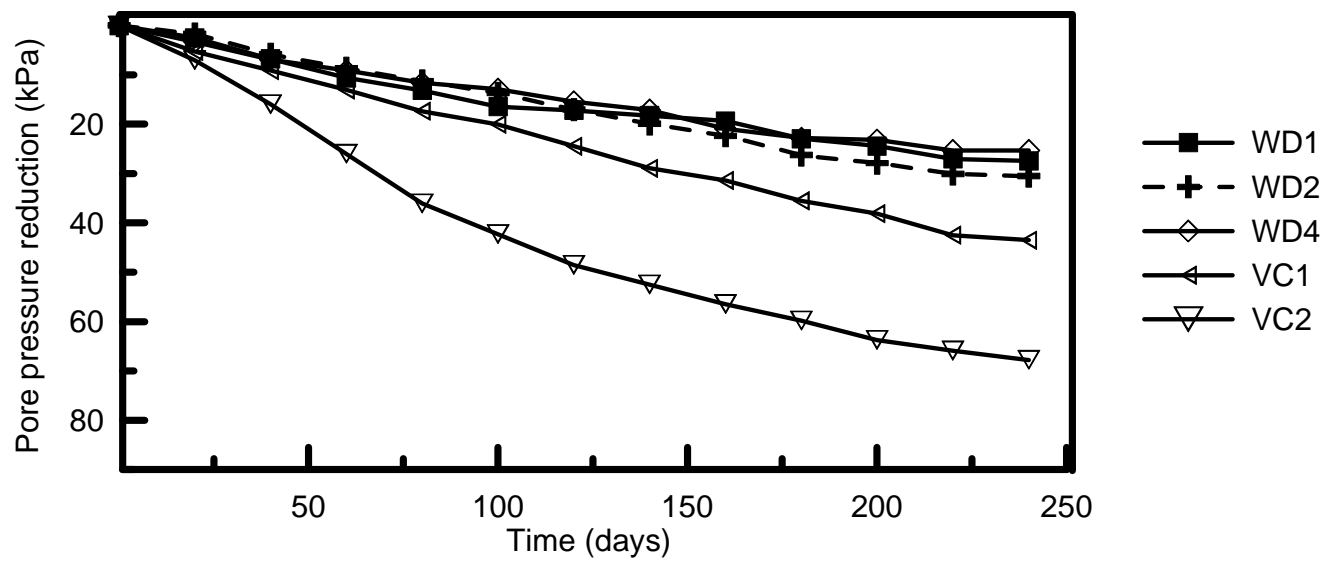

Figure 9. Pore pressure reduction after embankments reached the maximum height at various sections (Indraratna et al., 2011)

The measured horizontal displacement normalized to total change in applied stress (vacuum plus surcharge load) for two inclinometer locations (VC1/MS28 and WD3/MS27) and the variation of lateral displacement with time at selected depths (RL -7.19 m and -11.19 m) are presented in Figures 10 and 11, respectively. In VC1 and WD3 areas, the total load on the surface was almost the same. For the WD3 area, the total surcharge height was 4-5 m (90 kPa), whereas for the VC1 area the reduced surcharge pressure of $40 \mathrm{kPa}$ (2 m surcharge height) was supplemented with a vacuum pressure of $65 \mathrm{kPa}$. The highest lateral displacements normalised to the total change in total stress are observed within the Lower Holocene clay layer. The lateral displacements are lowest in the Holocene sand layer due to its greater stiffness. The ratio of maximum horizontal displacement to vertical displacement is a stability indicator (Indraratna et al., 1997), and its variation with time is shown in Figure 11. It can be seen that this ratio was significantly lower in the vacuum area (VC1) compared to the surcharge only area of WD3. These plots indicate that the lateral movements are well controlled via isotropic consolidation by vacuum pressure.

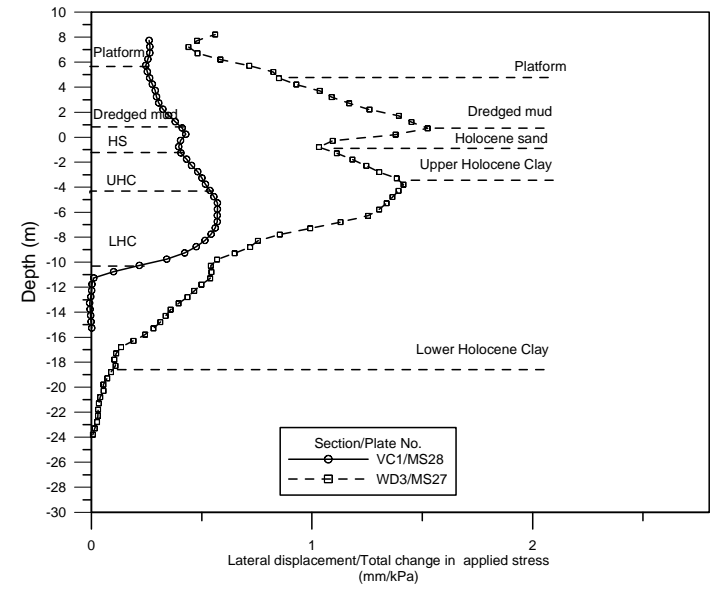

Figure 10: Comparison of lateral displacements at the embankment toe in vacuum and non-vacuum area after 400 days (Indraratna et al., 2011)

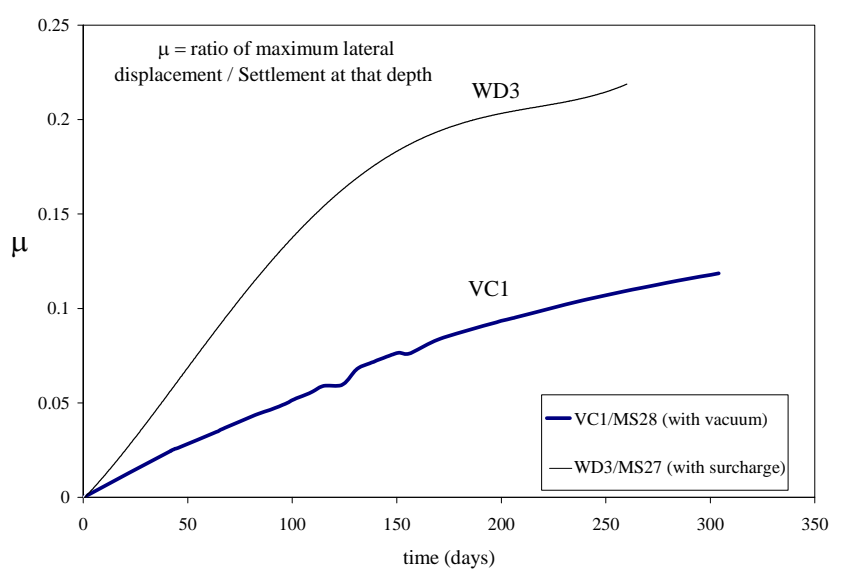

Figure 11: Lateral displacement/settlement with time (Indraratna et al., 2011) 
In order to predict excess pore pressures and associated settlements, Equations (11)-(21) are employed in conjunction with Tables 5 and 6 that summarise the soil properties for each layer and soil thickness for each section, respectively. In the analysis, the value of soil compression index $\left(C_{c}\right)$ obtained from the oedometer test is related to the actual stress state within a given region of the foundation. The vertical and horizontal coefficients of consolidation were determined using the oedometer and Rowe cells. For the completely remoulded dredged mud that was reclaimed from the seabed and Upper Holocene Sand the ratio $k_{h} / k_{s}$ were assumed to be unity. For the upper and lower Holocene clay, the ratios of $k_{h} / k_{s}$ and $d_{s} / d_{w}$ were assumed to be 2 and 3, respectively, in accordance with the laboratory tests conducted by Indraratna and Redana (2000).

Table 5. Soil profiles, equivalent drain diameter and drain influence zone diameter used for prediction (Indraratna et al., 2011)

\begin{tabular}{|c|c|c|c|c|c|l|}
\hline \multirow{2}{*}{ Area } & \multicolumn{5}{|c|}{ Layer Thickness (m) } & Drain \\
\cline { 2 - 7 } & $\begin{array}{l}\text { Dredged } \\
\text { mud }\end{array}$ & $\begin{array}{l}\text { Upper } \\
\text { Holocene } \\
\text { sand }\end{array}$ & $\begin{array}{l}\text { Upper } \\
\text { Holocene Clay }\end{array}$ & $\begin{array}{l}\text { Lower } \\
\text { Holocene Clay } \\
\text { diameter (m) }\end{array}$ & $\begin{array}{l}\text { Equivalent } \\
\text { drain } \\
\text { diameter } \\
(\mathrm{m})\end{array}$ \\
\hline WD1 & 2 & 1 & 4 & 11.5 & 1.23 & 0.034 \\
\hline WD2 & 2 & 1.5 & 2 & 19 & 1.57 & 0.034 \\
\hline WD3 & 2 & 1 & 2 & 8 & 1.24 & 0.05 \\
\hline WD4 & 2 & 1.5 & 2 & 21 & 1.47 & 0.05 \\
\hline WD5A & 0 & 1 & 2 & 8 & 1.36 & 0.05 \\
\hline WD5B & 2.5 & 1 & 2 & 7 & 1.24 & 0.05 \\
\hline VC1 & 2.5 & 2.5 & 2 & 5 & 1.36 & 0.034 \\
\hline VC2 & 0.5 & 3 & 2.5 & 16 & 1.36 & 0.034 \\
\hline
\end{tabular}

Table 6: Soil properties for each layer (Indraratna et al., 2011)

\begin{tabular}{|c|l|c|c|c|c|c|c|}
\hline $\begin{array}{l}\text { Soil } \\
\text { layer }\end{array}$ & Soil type & $\begin{array}{l}\gamma_{\mathbf{t}} \\
\left(\mathbf{k N} / \mathbf{m}^{\mathbf{3}}\right)\end{array}$ & $\mathbf{C c} / \mathbf{( 1 + \mathbf { e } _ { \mathbf { 0 } } )}$ & $\begin{array}{l}\boldsymbol{c}_{\boldsymbol{v}} \\
\left(\mathbf{m}^{\mathbf{2}} / \mathbf{y r}\right)\end{array}$ & $\begin{array}{l}\boldsymbol{c}_{\boldsymbol{h}} \\
\left(\mathbf{m}^{\mathbf{2}} / \mathbf{y r}\right)\end{array}$ & $\mathbf{k}_{\mathbf{h}} / \mathbf{k}_{\mathbf{s}}$ & $\mathbf{s}_{\mathbf{s}} \mathbf{d}_{\mathbf{s}} / \mathbf{d}_{\mathbf{w}}$ \\
\hline 1 & Dredged Mud & 14 & 0.235 & 1 & 1 & 1 & 1 \\
\hline 2 & Upper Holocene Sand & 19 & 0.01 & 5 & 5 & 1 & 1 \\
\hline 3 & Upper Holocene Clay & 16 & 0.18 & 1 & 2 & 2 & 3 \\
\hline 4 & Lower Holocene Clay & 16 & 0.2 & 0.8 & 1.9 & 2 & 3 \\
\hline
\end{tabular}

The embankment load was simulated according to a staged construction (with compacted unit weight of 20 $\mathrm{kN} / \mathrm{m}^{3}$ ). Settlement and associated excess pore pressure predictions were conducted at the embankment centreline using the proposed analytical model. As the computation of consolidation settlement and excess pore pressure at the centreline (zero lateral displacements) is straightforward and follows the basic 1-D consolidation theory, the use of a MATLAB spreadsheet formulation was most convenient. It is noted that, at the beginning of each subsequent stage, the initial in situ effective stress was calculated based on the final degree of consolidation of the previous stage. In vacuum areas, the suction pressure of $65 \mathrm{kPa}$ was used to compute the settlement and excess pore pressure.

Figures 12 and 13 show the calculated settlements and associated excess pore pressures with the measured data in Areas WD2 and VC2, where the total applied load (120-130 kPa) and clay thickness $(20-23 \mathrm{~m})$ are comparable. Overall, the comparisons between prediction and field observation show that the settlement and associated pore water pressure can be predicted very well. In vacuum areas, the degree of consolidation exceeded $90 \%$ at 400 days, whereas that in the non-vacuum area was less than $85 \%$ at the same time. This confirms that, at a given time, the vacuum combined preloading would accelerate consolidation faster than the surcharge preloading alone. This is because in non-vacuum areas, a gradual embankment construction had to be followed to avoid potential undrained failure in the remoulded dredged layer. 


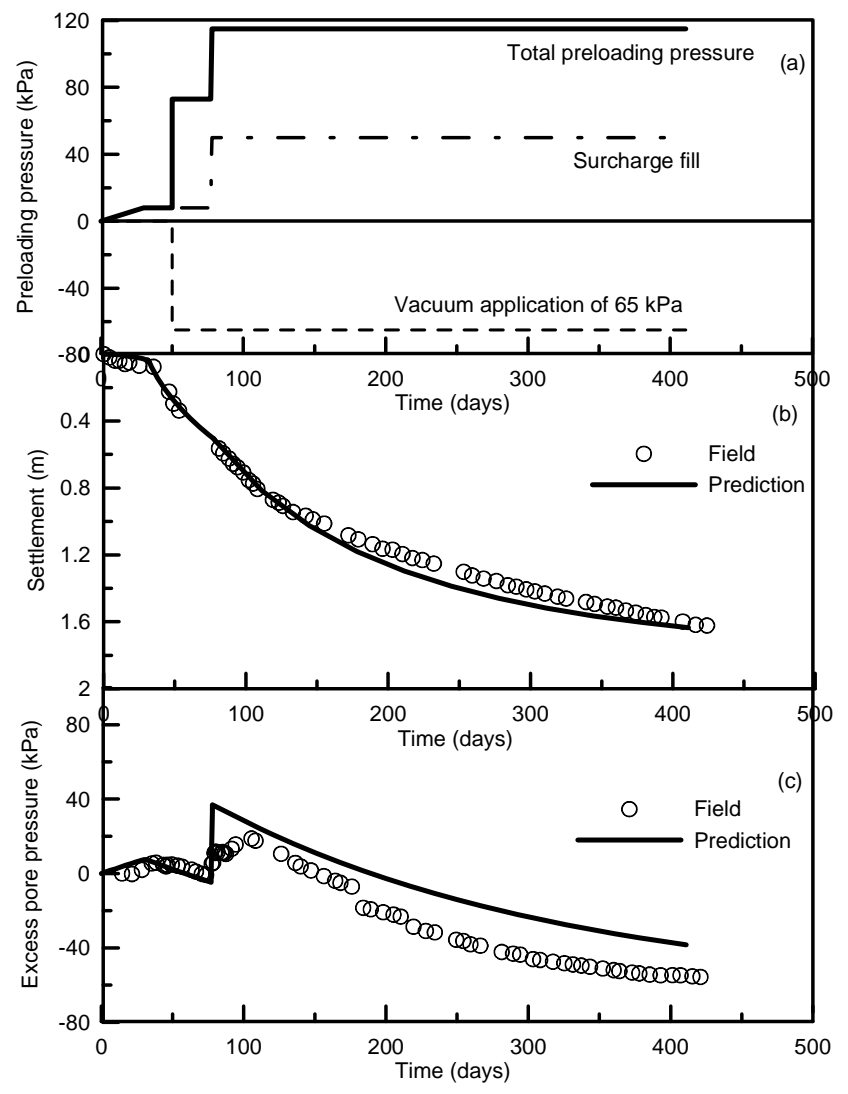

Figure 12: WD2 area: (a) stages of loading, (b) surface settlements under the embankment centreline and (c) excess pore pressures (Indraratna et al., 2011)

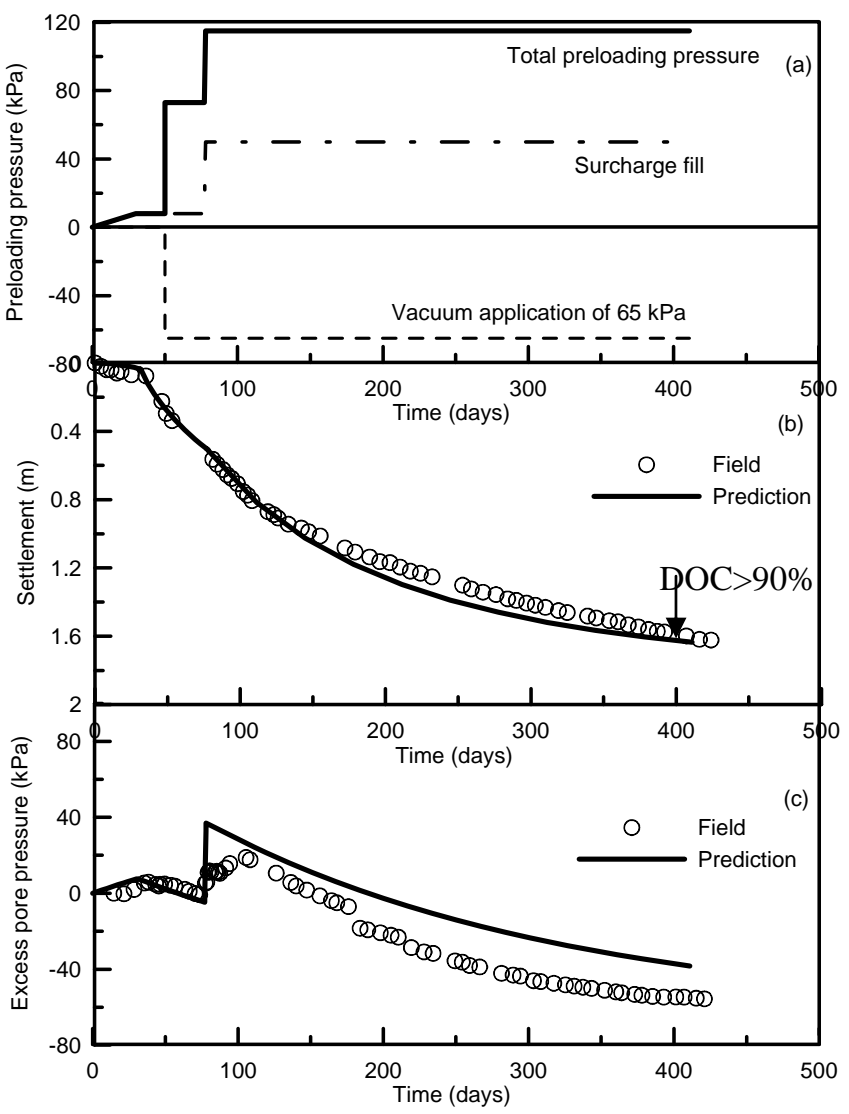

Figure 13: VC2 area: (a) stages of loading, (b) surface settlements under the embankment centreline and (c) excess pore pressures (Indraratna et al., 2011) 


\section{CONCLUSIONS}

A system of vertical drains with vacuum preloading is an effective method for speeding up soil consolidation. The performance of ground consolidation at the Port of Brisbane was analysed and discussed. The land was reclaimed using mud dredged from the seabed of shipping channels and berths. A total of 8 sections were chosen to study the behaviour of vacuum consolidation, the influence of the drain spacing and drain types. A membrane type vacuum consolidation system was utilised with an array of monitoring devices including settlements, piezometers and inclinometers. The average degree of consolidation achieved was more than $85 \%$ after 12 months. In the surcharge only areas, both band PVDs and circular PVDs yielded a similar performance based on the degree of consolidation. However, the circular drains performed better in vacuum areas probably because they can propagate vacuum pressure more effectively compared to band drains, thereby allowing a constant vacuum pressure at a greater depth. In terms of drain spacing, a spacing of 1.2-1.3 $\mathrm{m}$ is sufficient for design, as much closer drain spacing may create excessive disturbance due to overlapping smear zones. The excess pore pressure dissipation rate in the vacuum area was higher than the non-vacuum areas verifying that the vacuum pressure increases the lateral hydraulic gradient for promoting radial flow. The vacuum application also creates an inward lateral movement, whereas the conventional surcharge fill induces an outward movement. When the vacuum pressure combined with surcharge fill is adopted, the overall lateral movement can be curtailed due to the isotropic consolidation induced by vacuum application. From a stability point of view, vacuum pressure decreases the ratio of lateral displacement to surcharge fill height at any given time.

The unit cell theory considering time-dependent surcharge load and vacuum application was developed to predict the settlement and the associated excess pore pressure, which were shown to be in good agreement with the field measurements. At 400 days, the degree of consolidation in the vacuum areas is much greater than the non-vacuum areas for the same total stress applied at the surface. The system of PVDs subjected to vacuum combined surcharge preloading is a useful method for accelerating the radial consolidation and for controlling the lateral displacement. While the analytical model discussed here is a useful tool to predict the performance of soft clay stabilized by PVDs, the accurate modelling of pressure preloading requires field observation to examine the correct vacuum pressure distribution, as the fluctuation of suction with time and with depth has not been uncommon in numerous case studies.

\section{ACKNOWLEDGEMENTS}

The writers acknowledge the support of the Port of Brisbane Corporation, Coffey Geotechnics and Austress Menard. The research funding from the Australia Research Council is acknowledged. The assistance of Prof. A.S. Balasubramaniam of Griffith University, Daniel Berthier of Austress Menard Bachi, Prof Harry Poulos, Cynthia De Bok, Tine Birkemose and Chamari Bamunawita of Coffey Geotechnics is appreciated. More elaborate details of the contents discussed in the paper can also be found in previous publications of the first Author and his research students in ASCE and Canadian Geotechnical Journals, since the mid 1990's. Valuable comments from A/Prof Hadi Khabbaz of UTS are greatly appreciated.

\section{REFERENCES}

Ameratunga, J., Boyle, P., De Bok, C. and Bamunawita, C. (2010). Port of Brisbane (PoB) Clay Characteristics and Use of Wick Drains to Improve Deep Soft Clay Deposits. Proceedings 17th Asian Geotechnical Conference, Taipei, Vol I, pp 116-119.

Austress Menard (2008). Personal communication internal report and confidential, 79p.

Berthier, D., Boyle, P., Ameratunga, J., De Bok, C. and Vincent, P. (2009). A successful trial of vacuum consolidation at in the Port of Brisbane. PIANC 2009, Christchurch, New Zealand (in CD).

Chai, J.C., Carter, J.P., and Hayashi, S. (2005). Ground deformation induced by vacuum consolidation. Journal of Geotechnical and Geoenvironmental Engineering, 131(12):1552-1561.

Chu, J. Yan, S.W., and Yang, H. 2000. Soil improvement by the vacuum preloading method for an oil storage station. Geotechnique, 50(6): 625-632.

Geng, X. Y., Indraratna, B. and Rujikiatkamjorn, C. (2011). Analytical solutions for a single vertical drain with vacuum and time-dependent surcharge preloading in membrane and membraneless systems. International Journal of Geomechanics, ASCE, (Accepted December 2011).

Holtz, R. D., Jamiolkowski, M., Lancellotta, R. and Pedroni, S. (1991). Prefabricated vertical drains: design and performance. CIRIA ground engineering report: ground improvement. Butterworth-Heinemann Ltd, UK, 131.

Indraratna, B. and Redana, I. W. (2000). Numerical modeling of vertical drains with smear and well resistance installed in soft clay. Canadian Geotechnical Journal, 37: 132-145. 
Indraratna, B., Balasubramaniam, A.S. and Sivaneswaran (1997). Analysis of Settlements and Lateral Deformation of Soft Clay Foundation beneath Two Embankments. International Journal of Numerical and Analytical Methods inGeomechanics, 31(9): 599-618.

Indraratna, B., Sathananthan, I., Rujikiatkamjorn C. and Balasubramaniam, A. S. (2005). Analytical and numerical modelling of soft soil stabilized by PVD incorporating vacuum preloading. International Journal of Geomechanics, 5(2). 114-124.

Indraratna, B., Rujikiatkamjorn, C., Ameratunga, J., and Boyle, P. (2011) Performance and Prediction of Vacuum Combined Surcharge Consolidation at Port of Brisbane. J. of Geotechnical \& Geoenvironmental Engineering, ASCE (Accepted in January 2011).

Mohamedelhassan, E., and Shang, J.Q. (2002). Vacuum and surcharge combined one-dimensional consolidation of clay soils. Can. Geotech. J. 39: 1126-1138.

Port of Brisbane Corporation (2009). Annual report 2008/2009, Port of Brisbane Corporation, Brisbane, Queensland, 92p.

Rujikiatkamjorn, C., Indraratna, B. and Chu, J. 2008. 2D and 3D numerical modeling of combined surcharge and vacuum preloading with vertical drains. International Journal of Geomechanics, 8(2): 144-156.

Shang, J.Q., Tang, M., and Miao, Z. (1998). Vacuum preloading consolidation of reclaimed land: a case study. Canadian Geotechnical Journal, 35: 740-749.

Yan, S.W. and Chu, J. (2003). Soil improvement for a road using a vacuum preloading method. Ground Improvement, 7(4): 165-172. 


\section{APPENDIX 1: ANALYTICAL SOLUTIONS}

\section{A. Membrane system}

The pore water pressure within the vertical drain and the average pore water pressure for membrane system, which can be solved by considering the applicable boundary conditions and loading pattern (detailed derivations can be found in Appendix A), in the Laplace frequency domain are:

$$
\begin{aligned}
& \hat{u}_{w 1}(Z, S)=X_{1} e^{a_{1} Z}+X_{2} e^{-a_{1} Z}+X_{3} e^{a_{2} Z}+X_{4} e^{-a_{2} Z}+\hat{Q}(S) \\
& \hat{u}_{w 2}(Z, S)=Y_{1} e^{b_{1} Z}+Y_{2} e^{-b_{1} Z}+Y_{3} e^{b_{2} Z}+Y_{4} e^{-b_{2} Z}+\hat{Q}(S) \\
& \hat{\bar{u}}_{1}(Z, S)=X_{1}\left(1-\frac{a_{1}^{2}}{B_{2}}\right) e^{a_{1} Z}+X_{2}\left(1-\frac{a_{1}^{2}}{B_{2}}\right) e^{-a_{1} Z}+X_{3}\left(1-\frac{a_{2}^{2}}{B_{2}}\right) e^{a_{2} Z}+X_{4}\left(1-\frac{a_{2}^{2}}{B_{2}}\right) e^{-a_{2} Z}+\hat{Q}(S) \\
& \hat{\bar{u}}_{2}(Z, S)=Y_{1}\left(1-\frac{b_{1}^{2}}{B_{4}}\right) e^{b_{1} Z}+Y_{2}\left(1-\frac{b_{1}^{2}}{B_{4}}\right) e^{-b_{1} Z}+Y_{3}\left(1-\frac{b_{2}^{2}}{B_{4}}\right) e^{b_{2} Z}+Y_{4}\left(1-\frac{b_{2}^{2}}{B_{4}}\right) e^{-b_{2} Z}+\hat{Q}(S)
\end{aligned}
$$

where,

$$
\begin{aligned}
& a_{1}=\sqrt{\frac{\left(\frac{\Theta}{C}+B_{1}+B_{2}\right)+\sqrt{\left(\frac{\Theta}{C}+B_{1}+B_{2}\right)^{2}-4 \frac{\Theta}{C} B_{2}}}{2}} \\
& a_{2}=\sqrt{\frac{\left(\frac{\Theta}{C}+B_{1}+B_{2}\right)-\sqrt{\left(\frac{\Theta}{C}+B_{1}+B_{2}\right)^{2}-4 \frac{\Theta}{C} B_{2}}}{2}} \\
& b_{1}=\sqrt{\frac{\left(\Theta+B_{3}+B_{4}\right)+\sqrt{\left(\Theta+B_{3}+B_{4}\right)^{2}-4 \Theta B_{4}}}{2}} \\
& b_{2}=\sqrt{\frac{\left(\Theta+B_{3}+B_{4}\right)-\sqrt{\left(\Theta+B_{3}+B_{4}\right)^{2}-4 \Theta B_{4}}}{2}} \\
& \Theta=\frac{S K_{3} h_{2}^{2}}{n^{2}}
\end{aligned}
$$

By considering the boundary conditions (Equations 10a-10f), the continuity conditions at the interface between the underlying soil and sand blanket (Equations 10g-10j), and the initial condition (Equation 10k), the following matrix can be obtained to get $X_{i}$ and $Y_{i}(i=1,2,3,4)$ :

$$
\xi_{8 \times 8} \psi^{T}=P^{T}
$$

where $\xi_{8 \times 8}$ as Appendix A shows,

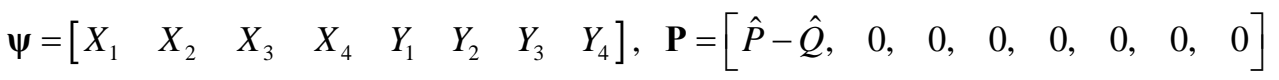

$$
\begin{aligned}
& B_{1}=\frac{8 K_{1} h_{2}^{2}}{F_{a 1} n^{2}}, \quad B_{2}=\frac{8 h_{2}^{2}\left(n^{2}-1\right) K_{2}}{F_{a 1} n^{2}}, \quad B_{3}=\frac{8 K_{3} h_{2}^{2}}{F_{a 2} n^{2}}, \quad B_{4}=\frac{8 h_{2}^{2}\left(n^{2}-1\right) K_{4}}{F_{a 2} n^{2}} \text {, } \\
& F_{a 1}=\left(\ln n-\frac{3}{4}\right) \frac{n^{2}}{n^{2}-1}+\frac{1}{n^{2}-1}\left(1-\frac{1}{4 n^{2}}\right) \text {, } \\
& F_{a 2}=\left(\ln \frac{n}{m}+K_{5} \ln m-\frac{3}{4}\right) \frac{n^{2}}{n^{2}-1}+\frac{m^{2}}{n^{2}-1}\left(1-K_{5}\right)\left(1-\frac{m^{2}}{4 n^{2}}\right)+K_{5} \frac{1}{n^{2}-1}\left(1-\frac{1}{4 n^{2}}\right), \\
& n=\frac{r_{e}}{r_{w}}, \quad m=\frac{r_{s}}{r_{w}}, s=r_{s} / r_{w}, c_{v i}=\frac{k_{v i}}{m_{v i} \gamma_{w}}, c_{h i}=\frac{k_{h i}}{m_{v i} \gamma_{w}}, K_{1}=\frac{k_{h 1}}{k_{v 1}}, K_{2}=\frac{k_{h 1}}{k_{w}}, K_{3}=\frac{k_{h 2}}{k_{v 2}}, K_{4}=\frac{k_{h 2}}{k_{w}} \text {, } \\
& K_{5}=\frac{k_{h 2}}{k_{s 2}}, h_{2}=\frac{H}{d_{w}}, T_{h 2}=\frac{c_{h 2} \cdot t}{d e^{2}}, C=\frac{c_{v 1}}{c_{v 2}}, Z=\frac{Z}{H} \text {. }
\end{aligned}
$$


And $\hat{u}_{w 1}(Z, S), \hat{u}_{w 2}(Z, S), \quad \hat{\bar{u}}_{1}(Z, S), \hat{\bar{u}}_{2}(Z, S), \hat{Q}(S), S$ is the Laplace transform of $u_{w 1}\left(Z, T_{h 2}\right)$, $u_{w 2}\left(Z, T_{h 2}\right), \bar{u}_{1}\left(Z, T_{v 1}\right), \bar{u}_{2}\left(Z, T_{v 1}\right), q\left(T_{h 1}\right), T_{h 2}$.

The solutions to the excess pore water pressure $u_{w i}$ and average pore water pressure $\bar{u}_{i}(i=1,2)$ were obtained using the inverse Laplace transform of Equations (11) - (14), hence:

$$
\begin{aligned}
& u_{w i}(Z, S)=\frac{1}{2 \pi I} \int_{a-I_{\infty}}^{a+I \infty} \hat{u}_{w i}(Z, S) e^{S T} d S \quad(i=1,2) \\
& \bar{u}_{i}(Z, S)=\frac{1}{2 \pi I} \int_{a-I_{\infty} \infty}^{a+I_{i}} \hat{\bar{u}}_{i}(Z, S) e^{S T} d S \quad(i=1,2)
\end{aligned}
$$

where, $I=\sqrt{-1}$. The analytical solutions of Equations (16) and (17) were obtained using the numerical inversion of Laplace transform.

\section{B. Membraneless system}

Similar as the membrane system, the pore water pressure within the vertical drain and the average pore water pressure for membraneless system, which can be solved by considering the applicable boundary conditions and loading pattern (Appendix A), in the Laplace frequency domain are:

$$
\begin{gathered}
\hat{u}_{w}(Z, S)=\chi_{1} e^{b_{1} Z}+\chi_{2} e^{-b_{1} Z}+\chi_{3} e^{b_{2} Z}+\chi_{4} e^{-b_{2} Z}+\hat{Q}(S) \\
\hat{\bar{u}}(Z, S)=\chi_{1}\left(1-\frac{b_{1}^{2}}{B_{6}}\right) e^{b_{1} Z}+\chi_{2}\left(1-\frac{b_{1}^{2}}{B_{6}}\right) e^{-b_{1} Z}+\chi_{3}\left(1-\frac{b_{2}^{2}}{B_{6}}\right) e^{b_{2} Z}+\chi_{4}\left(1-\frac{b_{2}^{2}}{B_{6}}\right) e^{-b_{2} Z}+\hat{Q}(S)
\end{gathered}
$$

The matrix from the Equations (18) and (19) are determined by:

$$
\xi_{4 \times 4}^{\prime} \psi^{\prime T}=P^{\prime T}
$$

where

$\xi^{\prime}$ as Appendix A shows,

$$
\begin{aligned}
& \boldsymbol{\psi}^{\prime}=\left[\begin{array}{llll}
\chi_{1} & \chi_{2} & \chi_{3} & \chi_{4}
\end{array}\right], \mathbf{P}^{\prime}=\left[\begin{array}{lll}
\hat{P}-\hat{Q}, & 0, \quad(\eta-1) \hat{P}, & 0
\end{array}\right] \\
& F_{a}=\left(\ln \frac{n}{m}+K_{5} \ln m-\frac{3}{4}\right) \frac{n^{2}}{n^{2}-1}+\frac{m^{2}}{n^{2}-1}\left(1-K_{5}\right)\left(1-\frac{m^{2}}{4 n^{2}}\right)+K_{5} \frac{1}{n^{2}-1}\left(1-\frac{1}{4 n^{2}}\right) \\
& B_{5}=\frac{8 K_{3} h_{2}^{2}}{n^{2} F_{a}}, B_{6}=\frac{8 h_{2}^{2}\left(n^{2}-1\right) K_{4}}{F_{a 2} n^{2}} \text {. }
\end{aligned}
$$

Using the inverse Laplace transform, the excess pore water pressure $u_{w}$ and average pore water pressure $\bar{u}$ can be obtained.

The settlement of the soil is given by:

$$
s(t)=\int_{L_{w}}^{H} \varepsilon_{2} d z
$$

Theoretically, the average degree of consolidation may be defined either in terms of strain or pore pressure. While the former shows the rate of settlement, the latter indicates the dissipation rate of excess pore water pressure.

The average degree of consolidation in terms of settlement can be expressed as:

$$
\bar{U}_{s}=1-\frac{m_{v 1} \int_{0}^{\rho} L^{-1}\left(\hat{\bar{u}}_{1}\right) d Z+m_{v 2} \int_{\rho}^{1} L^{-1}\left(\hat{\bar{u}}_{2}\right) d Z}{m_{v 1} \int_{0}^{\rho}\left(q_{u}-p\right) d Z+m_{v 1} \int_{\rho}^{1}\left(q_{u}-p\right) d Z}
$$

The average degree of consolidation may be defined in terms of effective stress (i.e. dissipation of excess pore water pressure) as:

$$
\bar{U}_{p}=1-\frac{\int_{0}^{\rho} L^{-1}\left(\hat{\bar{u}}_{1}\right) d Z+\int_{\rho}^{1} L^{-1}\left(\hat{\bar{u}}_{2}\right) d Z}{\int_{0}^{\rho}\left(q_{u}-p\right) d Z+\int_{\rho}^{1}\left(q_{u}-p\right) d Z}
$$


PERFORMANCE AND PREDICTION OF VACUUM COMBINED SURCHARGE CONSOLIDATION AT PORT OF BRISBANE

INDRARATNA ET AL. 